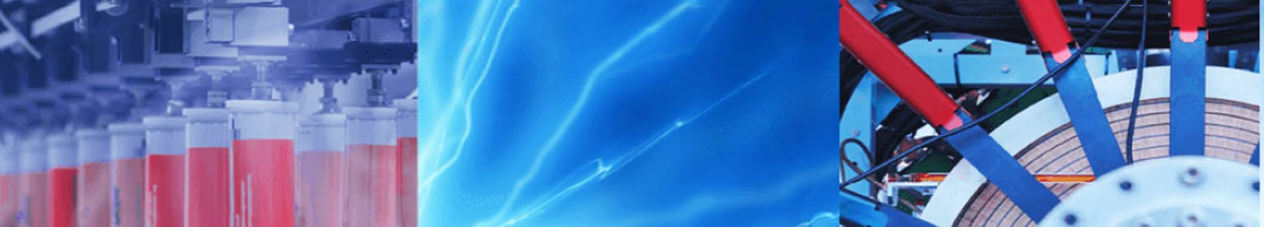

Research Article

\title{
Steam-cured recycled aggregate concrete incorporating moderately high early strength cement: effect of binder content and curing conditions
}

\author{
Yongjae $\mathrm{Kim}^{1} \cdot$ Wonjun Park ${ }^{1} \cdot$ Asad Hanif $^{2}$ (i)
}

() Springer Nature Switzerland AG 2019

\begin{abstract}
Steam curing employed for faster strength gain due to higher hydration rate may lead to shrinkage issues, and hence the use of moderately high early strength cement (MESC) is proposed instead of typically used high early strength cement (HESC) which has a high C3S content. This paper evaluates the suitability of MESC for use in precast concrete. The objective was to (i) determine the feasibility of MESC in recycled aggregate concrete (RAC), (ii) determine the optimum steam curing conditions (curing duration, maximum temperature, and duration of holding maximum temperature), and (iii) evaluating the beneficial use of reduced binder content to compensate for steam curing. Four series of RAC were developed which were subjected to nine different steam curing condition, and the resulting strength properties were determined. Though all the developed concrete specimens achieved the design strength of $30 \mathrm{MPa}$, those cured at $50^{\circ} \mathrm{C}$ with $1 \mathrm{~h}$ duration of exposure to maximum temperature exhibited the best performance. Further, it was found that even though reducing the binder content reduces the ultimate strength at 28 -day age, curing at $70^{\circ} \mathrm{C}$ with $2 \mathrm{~h}$ exposure to maximum temperature duration (for $7 \%$ reduction in binder volume) leads to merely $11.8 \%$ strength decline. It is concluded that MESC can be effectively used in steam cured RAC instead of OPC and HESC with meagre strength loss when cured at maximum temperature of $50^{\circ} \mathrm{C}$ maintained for $1 \mathrm{~h}$ while the total curing time being $4.5 \mathrm{~h}$. Thus, utilizing MESC in RAC shall not only help combat the persistently declining natural resources but also reduced the associated carbon dioxide emissions, thereby promoting sustainable development.
\end{abstract}

Keywords Recycled aggregate $\cdot$ Steam curing $\cdot$ Waste recycling $\cdot$ Concrete $\cdot$ Mechanical properties $\cdot$ Moderately high early strength $\cdot$ Sustainable construction

\section{Introduction}

Persistently depleting natural resources have led the construction industry to adopt alternative materials, processes, and techniques to attain sustainable development through "reduce, reuse, and recycle" approach. The three pillars of sustainability including economic viability, societal acceptance, and environmental friendliness [1, 2] further establish the guiding principles for construction industry. Therefore, since the past few decades major technological advancement has been seen in construction materials including (i) use of alternative binders like geopolymers [3], magnesium phosphate cement [4, 5], and magnesium oxychloride cement $[6,7]$, (ii) use of supplementary cementing materials in concrete $[8,9]$, and (iii) use of waste or recycled aggregates in concrete $[10,11]$ such as sanitary ceramic waste [12], brick ceramic wastes [13], glass waste [14], and plastic waste [15]. Among the aforementioned techniques, waste aggregate recycling has gained special interest among the researchers as it

\footnotetext{
$\triangle$ Asad Hanif, ahanif@connect.ust.hk; asadhanif@um.edu.mo; asadhanif193@gmail.com | Department of Civil Engineering, Kangwon National University, 346, Jungang-ro, Samcheok-si, Gangwon-do 25913, South Korea. ${ }^{2}$ Institute of Applied Physics and Materials Engineering, University of Macau, Avenida de Universidade, Taipa, Macau, SAR, China.
}

SN Applied Sciences (2019) 1:445 | https://doi.org/10.1007/s42452-019-0472-x 
reduces the environmental burden due to lower associated $\mathrm{CO}_{2}$ emissions $[16,17]$ and saving the inconvenience of dumping the waste concrete in landfill.

Since the use of recycled aggregates (RA) in concrete, researchers have been trying to investigate the usefulness of using RA in concrete. In this regards, various experimental findings have shown clearly that using RA in lieu of natural aggregates (NA) leads to inferior resulting properties making the recycled aggregate concrete (RAC) use in less important structures $[18,19]$. However, this narrative was proven wrong by using a blend of aggregates and incorporating micro or nano fillers in concrete for improved mechanical attributes [20-24] Once the structural use of RAC was established, it opened further doors for researchers to explore its applicability and limitations $[25,26]$. In this regards, the use of RA in precast construction industry is worth mentioning.

Precast concrete is employed to ensure (i) quality control, (ii) faster fabrication and construction, and (iii) ease of erection of structural elements at the construction site [27-30]. In order to attain speedy fabrication of precast elements, use of high early strength cement $[2,31]$ and steam curing $[16,17]$ has been shown beneficial. It is, however, interesting to see that only a handful of research findings are available on the determination of optimal steam curing regime parameters [32-34] which particularly deal with ordinary concrete. It is seen that it has become customary to adopt the typical steam curing as suggested in [35].

Steam curing is an energy intensive process, and it should be adopted for extremely demanding circumstances. Also, the curing parameters should be optimized to reduce energy wastage. $8 \mathrm{~h}$ curing cycle for normal concrete was proposed for SCC [32] whereas $60^{\circ} \mathrm{C}$ was suggested for UHPC [36]. In another work, it was proposed that for normal concrete use of high temperature steam curing (as high as $85^{\circ} \mathrm{C}$ ) is beneficial in improving the early-age strength [37]. Further, a few studies on steam cured RAC presented contradicting results $[38,39]$. Kou et al. attained improvement in resulting properties by subjecting the concrete to $18 \mathrm{~h}$ long curing cycle, which may be useful but economically unviable solution [38]. Thus, the need to further explore this less focused area, particularly for RAC is compelling rather overwhelming.

As discussed earlier, some of the published findings have comprehensively evaluated the suitability of steam curing in normal concrete, but these were only focused on concrete produced with ordinary Portland cement (OPC) as the binder. Evaluating the resulting properties for RAC containing MESC in these scenarios is imperative. Although RAC properties under steam curing have been evaluated previously, the studies on the determination of the optimum steam-curing conditions (like peak temperature, cycle length, and the holding duration of the maximum temperature) are sparse. Further, the properties of RAC made with MESC have not yet been determined. This demands an in-depth evaluation of the RAC properties containing MESC, and the determination of the optimum parameters for the steam-curing cycle.

This experimental study fills the current research gap by exploring various properties of steam-cured, high earlystrength RAC. The steam-curing conditions were also varied, so that the steam-curing conditions for optimum concrete properties could be ascertained. The novelty of this study lies in the determination of the optimum steamcuring parameters for recycled aggregate concrete, incorporating moderately high early strength cement.

\section{Materials and experimental methods}

\subsection{Raw materials}

The primary binders used in this study included ordinary Portland cement (OPC) and moderately high early strength cement (MESC). The materials characterization details have already been published earlier in [31] (specific gravity of OPC and MESC: 3.14 and 3.17; Blain surface area: $3340 \mathrm{~cm}^{2} / \mathrm{g}$ and $4490 \mathrm{~cm}^{2} / \mathrm{g}$; loss on ignition: $2.26 \%$ and $1.05 \%$, respectively, conforming to Korean Standards KSL5201-1989. The cement used was produced in the Republic of Korea by the Sungshin Portland Cement Co. Ltd.). Coarse and fine aggregates (both natural and recycled) are shown in Fig. 1, while the raw materials characteristics are reported in Table 1 and Fig. 2. These properties helped to determine a suitable mix-proportion (Table 2) for design strength and workability requirements. These tests were conducted under the guidelines of Korean Standards (KS) [40-43].

\subsection{Mixture proportioning and specimen casting}

The mix design procedure and concrete mixing, casting, and curing were done according to American Concrete Institute $(\mathrm{ACl})$ standards [44-46], and explained by the authors in previously published findings $[2$, $16,17,31,47]$ and are hence not repeated here. The mix proportions for each series are given in Table 2 . The design strength was $30 \mathrm{MPa}$ while the minimum target slump was set to $150 \mathrm{~mm}$ (aggregates were assumed in saturated surface dry (SSD) conditions in the mix formulation procedure, and water adjustment was made later based on the stock condition). The series mentioned in Table 2 were named in the nomenclature according to the binder and aggregate 
Fig. 1 Aggregates used in the experimental work [31]
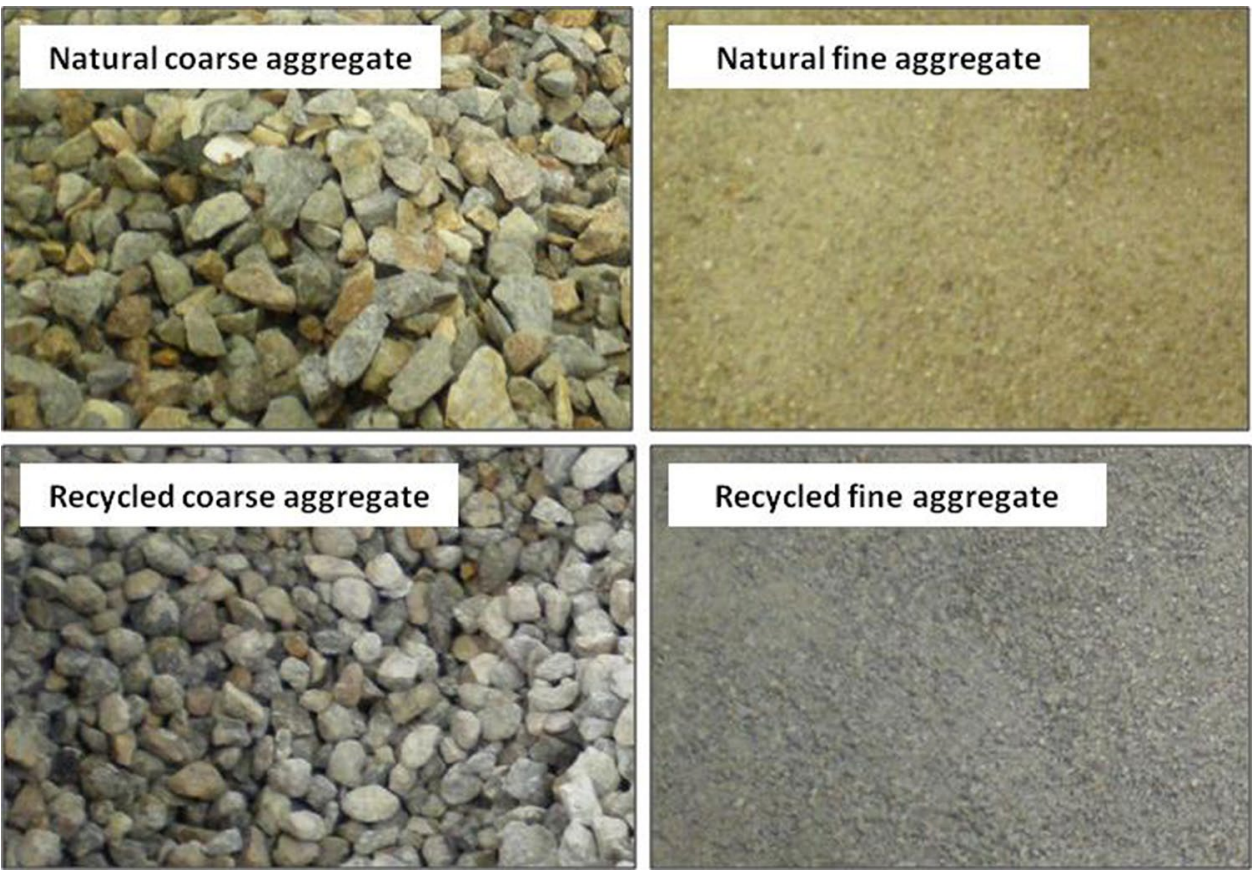

Table 1 Physical characteristics of the aggregates used in the experiment

\begin{tabular}{lllll}
\hline Raw materials & & $\begin{array}{l}\text { Maximum particle } \\
\text { size }(\mathrm{mm})\end{array}$ & Specific gravity & $\begin{array}{l}\text { Water } \\
\text { absorp- } \\
\text { tion (\%) }\end{array}$ \\
\hline Coarse aggregate & Natural & 25 & 2.69 & 0.91 \\
& Recycled & & 2.54 & 2.16 \\
Fine aggregate & Natural & 5 & 2.60 & 0.92 \\
& Recycled & & 2.44 & 5.17 \\
Cement & Ordinary portland & - & 3.14 & - \\
& Moderately high early & & 3.17 & - \\
\hline
\end{tabular}
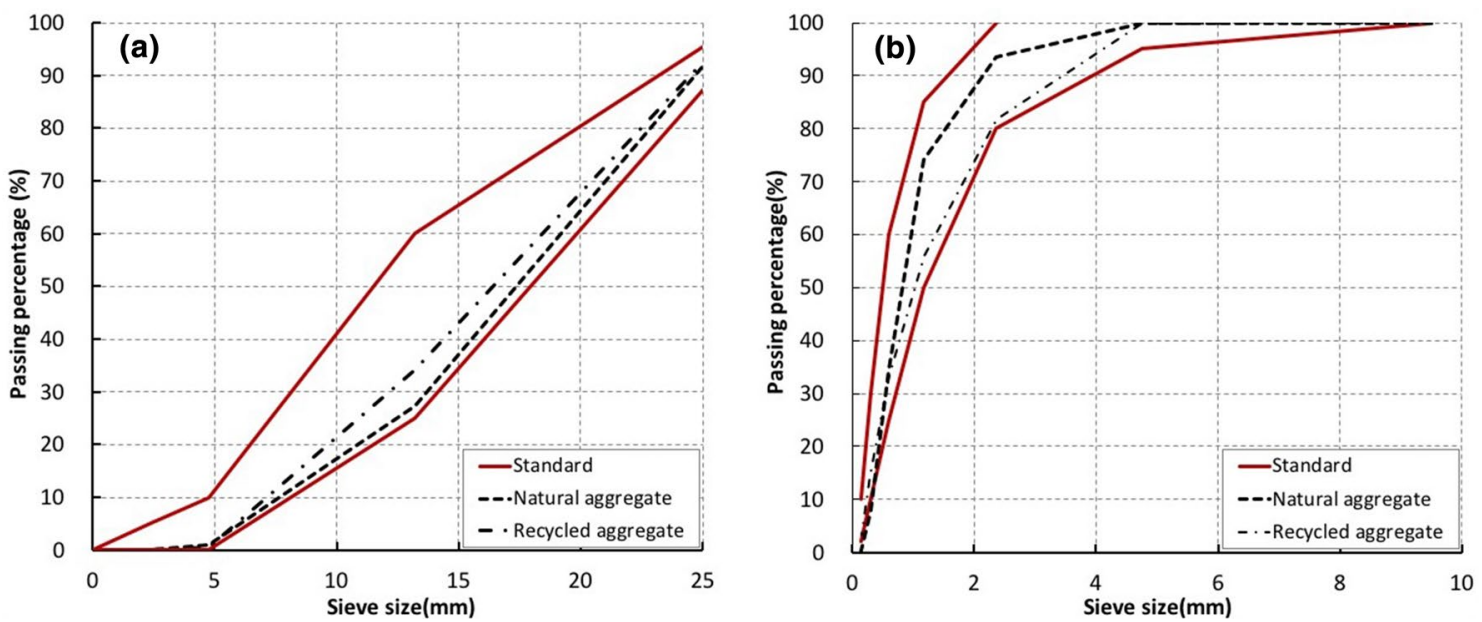

Fig. 2 Particle size distribution curve for $\mathbf{a}$ coarse aggregates, and $\mathbf{b}$ fine aggregates [31] 
Table 2 Mixture proportions (all quantities in $\mathrm{kg} / \mathrm{m} 3$ unless specified otherwise)

\begin{tabular}{|c|c|c|c|c|c|c|c|c|}
\hline \multirow[t]{3}{*}{ Variable } & \multirow[t]{3}{*}{$\mathrm{W} / \mathrm{C}$} & \multirow[t]{3}{*}{$S / a^{a}$} & \multicolumn{6}{|c|}{ Unit weight $\left(\mathrm{kg} / \mathrm{m}^{3}\right)$} \\
\hline & & & \multirow[t]{2}{*}{ W } & \multirow[t]{2}{*}{$\mathrm{C}$} & \multicolumn{2}{|c|}{ Fine aggregate } & \multicolumn{2}{|c|}{ Coarse aggregate } \\
\hline & & & & & Natural & Recycled & Natural & Recycled \\
\hline O100-N-60-4 & 36.4 & 43.8 & 155 & 425 & 751 & 0 & 998 & 0 \\
\hline M100-N-series & & & 155 & 429 & 751 & 0 & 998 & 0 \\
\hline M100-R-series & & & 155 & 429 & 451 & 282 & 399 & 565 \\
\hline M93-R-series & & & 144 & 399 & 465 & 291 & 411 & 583 \\
\hline M86-R-series & & & 133 & 369 & 479 & 299 & 424 & 600 \\
\hline
\end{tabular}

${ }^{\mathrm{a}} \mathrm{S} / \mathrm{a}$ is fine aggregate to total aggregate ratio type used to fabricate that particular mix. As indicated in Table 3, four series of concrete mixes were formulated while a control mix was also designed for comparison. The one named "O100-N-60-4" indicates that the mix was formulated for OPC binder, all natural aggregates, maximum temperature of steam curing as $60^{\circ} \mathrm{C}$ which was maintained for $4 \mathrm{~h}$. Similarly, "M100-Rseries" refers to the mix with MESC binder and recycled aggregates (optimum blend of aggregates as (40\% natural coarse $+60 \%$ recycled coarse) and ( $60 \%$ natural fine $+40 \%$ recycled fine) aggregates); it is further assigned different IDs based on the curing temperature and duration. The mix series with M93 and M86 refer to the mixes where the MESC binder volume is reduced by $7 \%$ and $14 \%$, respectively. As the total volume had to be kept constant for a fair comparison, the disparity was compensated by the increased aggregate volume. The quantities were then computed based on the corresponding specific gravity.

The aforementioned percentages of optimal blend of aggregates were based on previous studies $[16,17$, $28,29,48,49]$, which led to the determination of the optimum performance-based (strength and durability) blend of aggregates (natural and recycled). The concrete was mixed in a rotating drum type mixer. First, all of the required coarse aggregate was put in the mixer along with $50 \%$ of the cement. These were mixed for 1 min while progressively adding $50 \%$ of the required water. After $1 \mathrm{~min}$, the fine aggregate, remaining water, and cement were added while the mixer continued to rotate for three more minutes. Polycarboxylate Ether (PCE) based admixture was also used for improved flow characteristics particularly for RA containing mixes where the higher water absorption could lead to harsh mix. Admixtures were added simultaneously with the water. The whole mixing procedure took around $4 \mathrm{~min}$. Subsequently, the specimens were cast in molds of various sizes. Cylindrical specimens with a diameter of
$100 \mathrm{~mm}$ and a length of $200 \mathrm{~mm}$ were cast, for compressive strength testing [50].

\subsection{Steam-curing conditions employed in the study}

Specimens were subjected to steam curing under varying conditions (Fig. 3), e.g., the maximum steam-curing temperature and the maximum holding duration. The details of these parameters are already set out in Table 3. Another mix (O-N-60-4) was also formulated for the conventionally used steam-curing regimen. The nomenclature stipulated in Table 3 refers to five parameters, namely cement type, cement content, aggregate type, the maximum temperature of the steam-curing cycle, and the duration of holding/maintaining the maximum temperature of the curing cycle. For instance, the mix ID M86-R-70-2 refers to the concrete mix incorporating MESC as the primary binder with $14 \%$ (by volume) less binder content than the control, and the recycled aggregate blend (both for coarse and fine aggregates), with the maximum temperature of the steam-curing cycle set at $70^{\circ} \mathrm{C}$, maintained for $2 \mathrm{~h}$. The curing cycle was designed based on the empirical cycle length in accordance with the Portland Cement Association (PCA) [35]. Various parameters were employed in order to determine the optimum parameters based on the mechanical strength of the resulting concretes.

\subsection{Experimental methods and procedures}

The properties of the developed concretes (both in fresh and hardened states) were evaluated by various ASTM testing standards [50-54]. Figure 4 shows various steamcured samples being removed from the molds, and the compression testing setup. Fresh state properties were determined by a slump cone and digital air content meter (images are not shown due their common use in concrete 
Table 3 Mix details and steamcuring regimes employed

\begin{tabular}{|c|c|c|c|c|c|c|c|c|}
\hline \multirow[t]{2}{*}{ Nomenclature } & \multicolumn{2}{|l|}{ Binder } & \multicolumn{2}{|c|}{ Coarse aggregate } & \multicolumn{2}{|c|}{ Fine aggregate } & \multicolumn{2}{|l|}{ Curing } \\
\hline & $\overline{\text { Type }^{a}}$ & Vol & Natural & Recycled & Natural & Recycled & M.T. $\left({ }^{\circ} \mathrm{C}\right)$ & T.D. (h) \\
\hline $0100-N-60-4$ & $\mathrm{O}$ & $100 \%$ & $100 \%$ & $0 \%$ & $100 \%$ & $0 \%$ & 60 & 4 \\
\hline M100-N-50-0 & M & $100 \%$ & $100 \%$ & $0 \%$ & $100 \%$ & $0 \%$ & 50 & 0 \\
\hline M100-N-50-1 & & & & & & & & 1 \\
\hline M100-N-50-2 & & & & & & & & 2 \\
\hline M100-N-60-0 & & & & & & & 60 & 0 \\
\hline M100-N-60-1 & & & & & & & & 1 \\
\hline M100-N-60-2 & & & & & & & & 2 \\
\hline M100-N-70-0 & & & & & & & 70 & 0 \\
\hline M100-N-70-1 & & & & & & & & 1 \\
\hline M100-N-70-2 & & & & & & & & 2 \\
\hline M100-R-50-0 & & $100 \%$ & $40 \%$ & $60 \%$ & $60 \%$ & $40 \%$ & 50 & 0 \\
\hline M100-R-50-1 & & & & & & & & 1 \\
\hline M100-R-50-2 & & & & & & & & 2 \\
\hline M100-R-60-0 & & & & & & & 60 & 0 \\
\hline M100-R-60-1 & & & & & & & & 1 \\
\hline M100-R-60-2 & & & & & & & & 2 \\
\hline M100-R-70-0 & & & & & & & 70 & 0 \\
\hline M100-R-70-1 & & & & & & & & 1 \\
\hline M100-R-70-2 & & & & & & & & 2 \\
\hline M93-R-50-0 & & $93 \%$ & & & & & 50 & 0 \\
\hline M93-R-50-1 & & & & & & & & 1 \\
\hline M93-R-50-2 & & & & & & & & 2 \\
\hline M93-R-60-0 & & & & & & & 60 & 0 \\
\hline M93-R-60-1 & & & & & & & & 1 \\
\hline M93-R-60-2 & & & & & & & & 2 \\
\hline M93-R-70-0 & & & & & & & 70 & 0 \\
\hline M93-R-70-1 & & & & & & & & 1 \\
\hline M93-R-70-2 & & & & & & & & 2 \\
\hline M86-R-50-0 & & $86 \%$ & & & & & 50 & 0 \\
\hline M86-R-50-1 & & & & & & & & 1 \\
\hline M86-R-50-2 & & & & & & & & 2 \\
\hline M86-R-60-0 & & & & & & & 60 & 0 \\
\hline M86-R-60-1 & & & & & & & & 1 \\
\hline M86-R-60-2 & & & & & & & & 2 \\
\hline M86-R-70-0 & & & & & & & 70 & 0 \\
\hline M86-R-70-1 & & & & & & & & 1 \\
\hline M86-R-70-2 & & & & & & & & 2 \\
\hline
\end{tabular}

Cement volume of M93-R-series is 7\% less than cement volume of M100-R-series. But the aggregate volume of M93-R-series is higher than the aggregate volume of M100-R-series by the cement volume difference $(7 \%)$

M.T. Maximum temperature during steam curing

T.D. Time duration at maximum temperature

${ }^{a}$ Binder type (O: ordinary portland cement, $\mathrm{M}$ : moderately high early strength cement) testing). The specimens were tested at various curing ages, to assess their attributes at various hydration stages. The compressive strength testing was done by crushing the cylindrical specimen (100 $\mathrm{mm}$ diameter) in an automatic compression testing machine (5000 kN capacity), subjected to the loading rate of $2.4 \mathrm{kN} / \mathrm{s}[50]$. 
Fig. 3 Steam-curing regimes employed in the experimental program; a control series and steam-curing regimen holding the maximum temperature for $1 \mathrm{~h}$, b steam-curing regimen holding the maximum temperature for $1 \mathrm{~h}$, and c steamcuring regimen holding the maximum temperature for $2 \mathrm{~h}$. In this figure, it is important to note that the second letter of the series (-O-) is representative of corresponding aggregate type (which may be natural or blended recycled), Also, the symbol ' $M$ ' refers to the MESC for $100 \%, 93 \%$ or $86 \%$ binder volume as the case may be

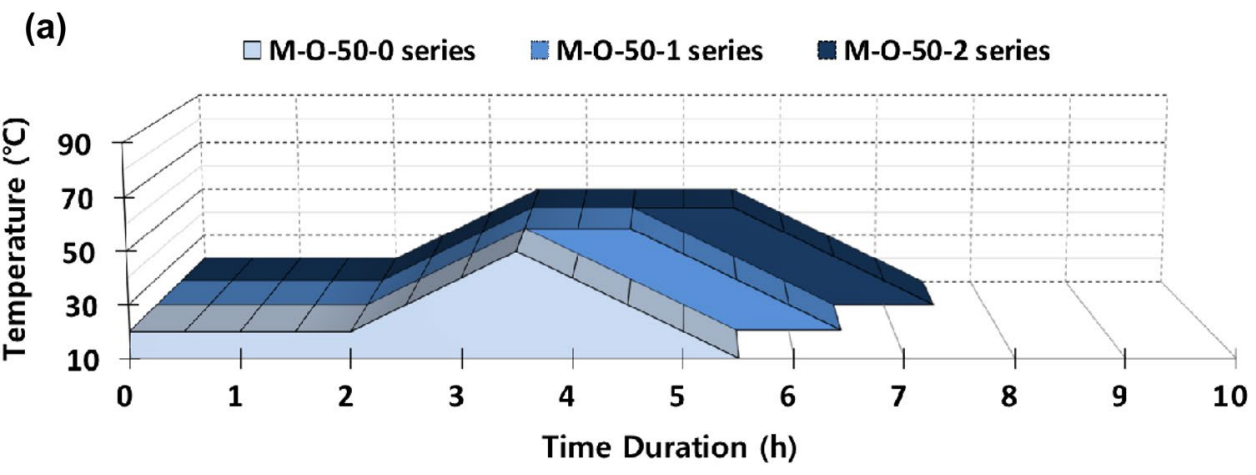

(b)

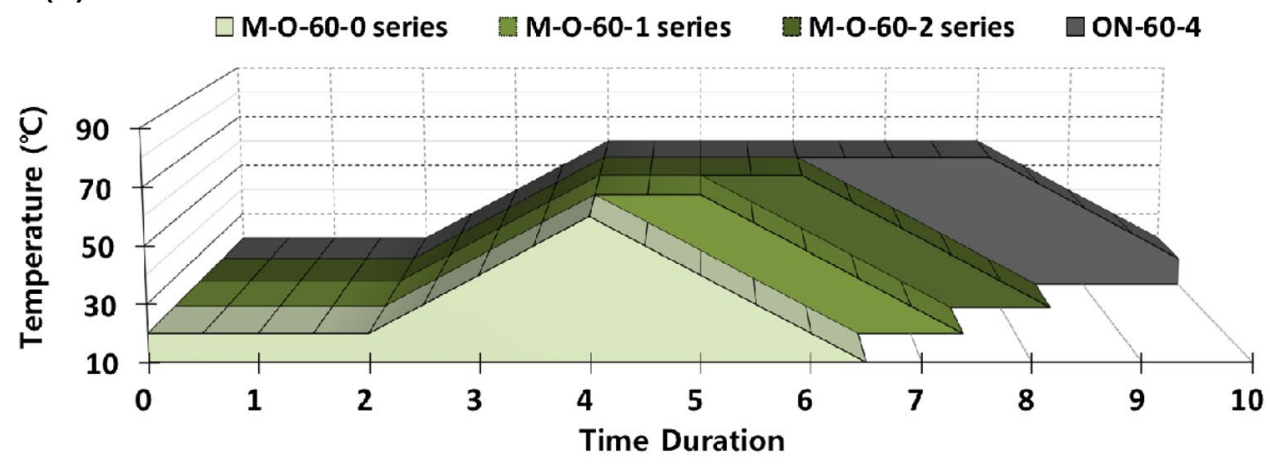

(c)

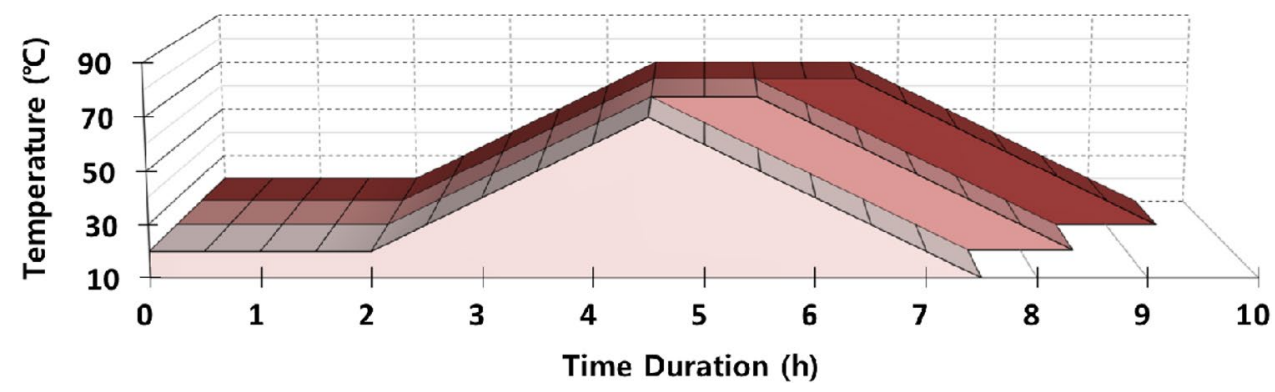

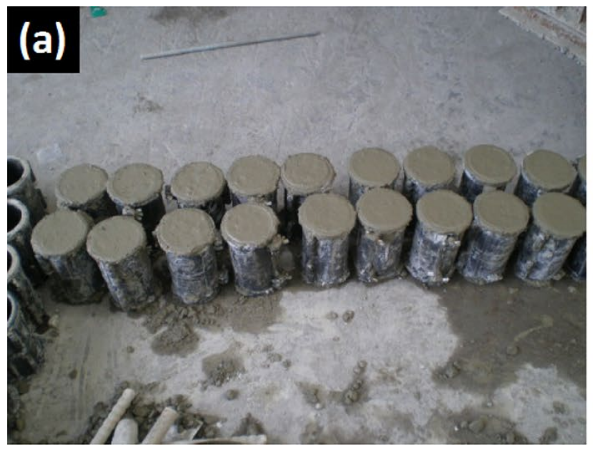
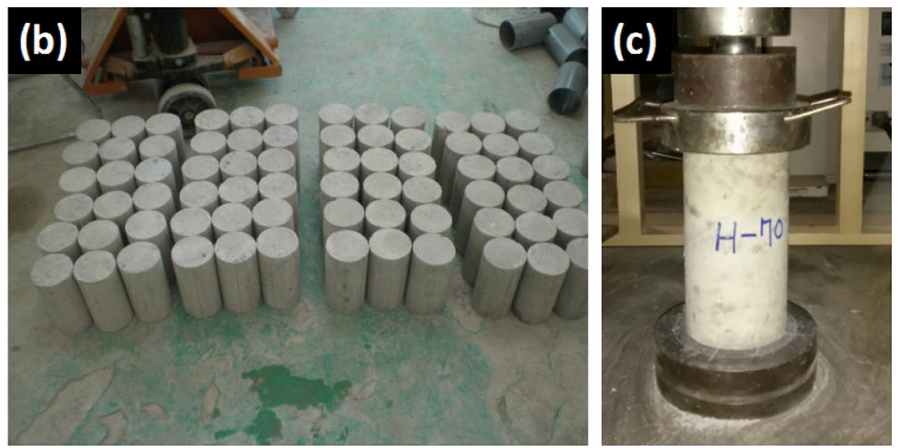

Fig. 4 a Freshly cast specimens, b demolded specimens after steam curing $[50,53]$ and $\mathbf{c}$ testing of specimens 


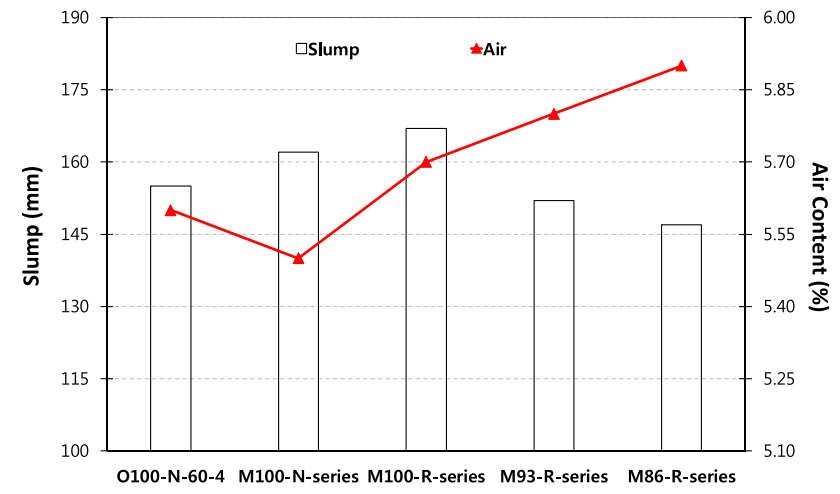

Fig. 5 Fresh state properties (slump and air content)

\section{Results, discussion, and analyses}

\subsection{Fresh state concrete properties}

The fresh state properties including the slump $(\mathrm{mm})$ and air content (\%) of the concretes are shown in Fig. 5. Both the cement and aggregate types affect the resulting properties in fresh state due to the different individual characteristics (surface area, particle size, specific gravity, particle shape, water absorption, etc.). Mixes containing $100 \%$ MESC showed higher workability, as indicated by the greater slump values. As the percentage volume of binder (MESC) reduced, the slump reduced as well. Also, recycled aggregates further increased the slump. The findings are similar to previously published results $[16,17,55]$ by the same authors. The rounded aggregates may upsurge/ increase the workability of fresh concrete due to a "ballbearing" effect [56]. As explained, such an effect can be attributed to the pretreatment (grinding, churning, and chemical processes) for adhered mortar removal, which may lead to the breaking of angular ends of aggregate particles, resulting in more spherical shapes [47].

The air content results were rather different to those obtained for the slump. The air content tended to increase in the concretes that contained recycled aggregates and MESC. This can be explained by the poor packing of the somewhat rounded aggregate shape (of recycled aggregates), in contrast to the angular grains (of natural aggregates). The greater air content also signified an anticipated decline in compressive strength, due to a greater void ratio and lower gel/space ratio. As the present study primarily focused on the effect of varying steam-curing conditions, the positive (or negative) effects will be reflected in the hardened concrete (as can be seen from the compressive strength results). It is, however, worth mentioning that the published literature on the fresh state properties of RAC contains disparities owing to the varying $\mathrm{w} / \mathrm{c}$ ratio, mixing method, and most importantly, the bonded/adhered mortar with the recycled aggregate surface $[57,58]$.

\subsection{Compressive strength}

The compressive strength results are shown in Figs. 6 and 7 . The values are averages of three specimens, while the SD/error was less than $4 \%$. Figure 6 shows the absolute values of the strength data obtained experimentally for specimens at various ages (1-day, 7-day, 14-day, and 28-day) while Fig. 7 shows the strength disparity due to varying parameters (aggregate, binder, and steam curing conditions).

Typically, strength increases with age is a common phenomenon associate with hydration. The greater the hydration, the higher is the gel/space ratio leading to increased strength. All the designed mixes reached the target of $30 \mathrm{MPa}$ for steam curing cycle of $50^{\circ} \mathrm{C}$ as the maximum temperature. On the other hand, the specimens subjected to higher temperature curing of $60^{\circ} \mathrm{C}$ and $70{ }^{\circ} \mathrm{C}$, led to target strength development at 28-day age, whereas a few of them (with MESC binder volume of $86 \%$ could not even reach the desired value. From these results, it can be well concluded that the MESC binder volume content should not be reduced by more than $7 \%$ in concrete mix design. Moreover, the curing temperature should not exceed $50^{\circ} \mathrm{C}$ for attaining superior mechanical properties.

It was observed that the compressive strength of the specimens decreased as the maximum temperature of the steam-curing cycle increased. A possibility for such anomaly might be the possible deterioration of hardened concrete due to excessive heating. However, this might not be similar to some of the previously published findings $[59,60]$ previous work which may be attributed to the cement type (Moderately High Early Strength Cement) and aggregate type (Recycled aggregates). A great disparity in strength was observed when compared to the control mix (O-N-60-4). This is consistent with the findings previously published by different authors [61, 62]. The maximum temperature for efficient curing under the same conditions, as used in this experiment, was estimated to be $50{ }^{\circ} \mathrm{C}$. The results are in agreement with the previous findings [63], where it was shown that the reduction in mechanical properties of the RAC was "more pronounced in water curing than in steam curing". Also, the precast concrete elements with RA incorporation using steam curing have been proven to meet the strength and durability requirements.

Another steam-curing parameter evaluated in this study was the duration for which the maximum temperature was maintained. The experimental study demonstrated that a 1-h holding duration of the maximum temperature 
Fig. 6 Compressive strength results of all of the mixes, in comparison with the control (a)

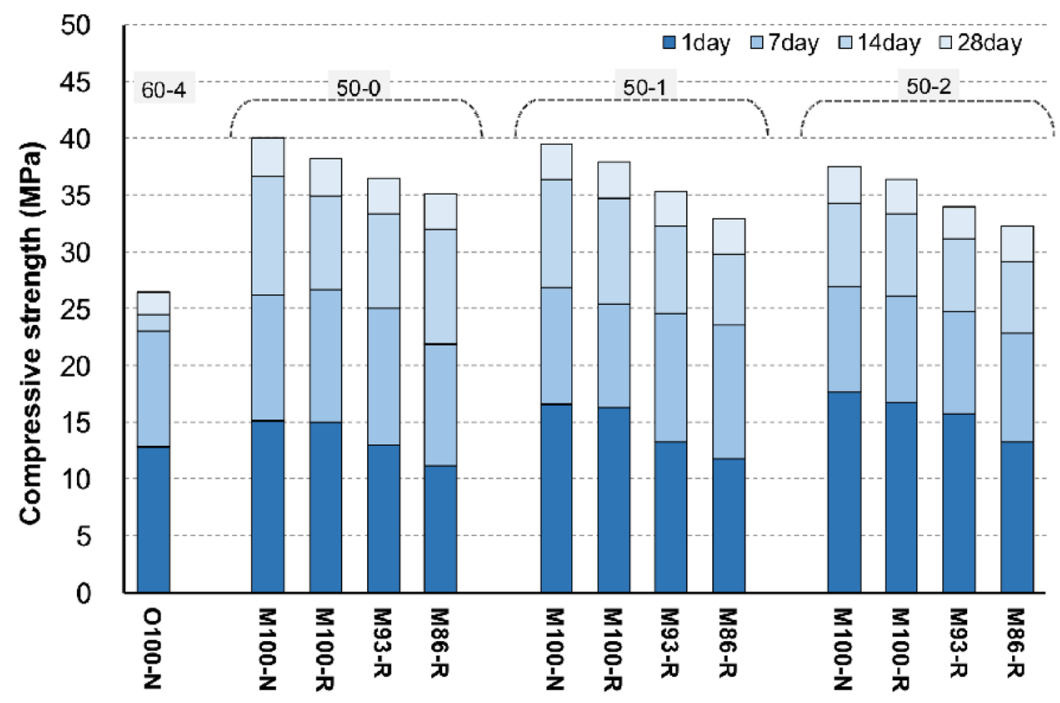

(b)

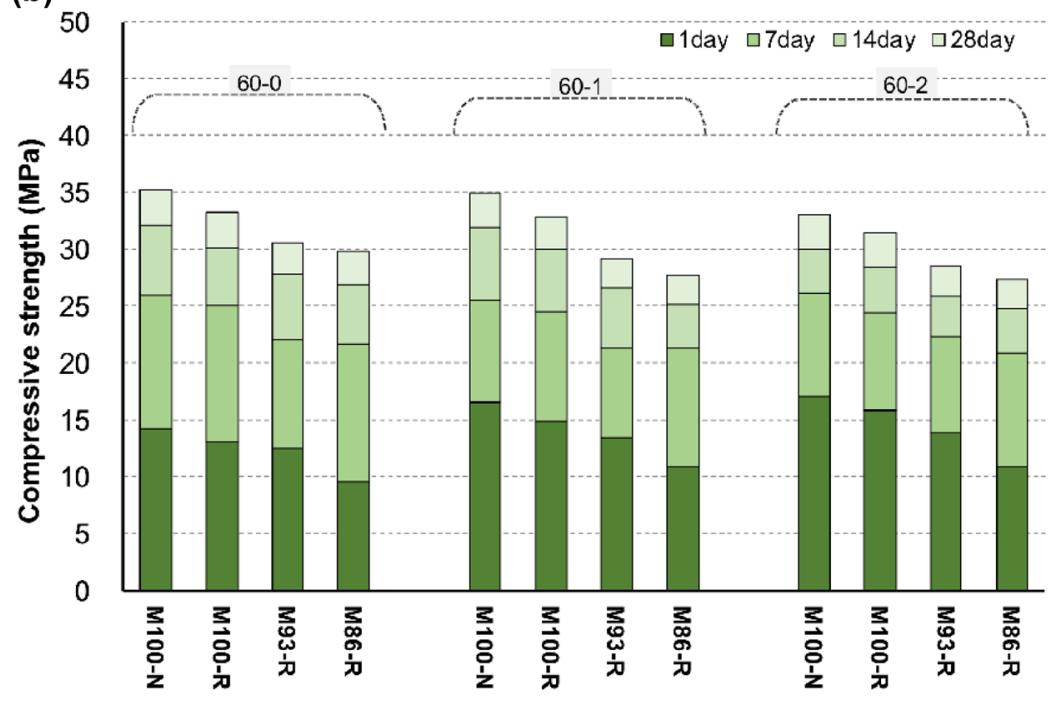

(c)

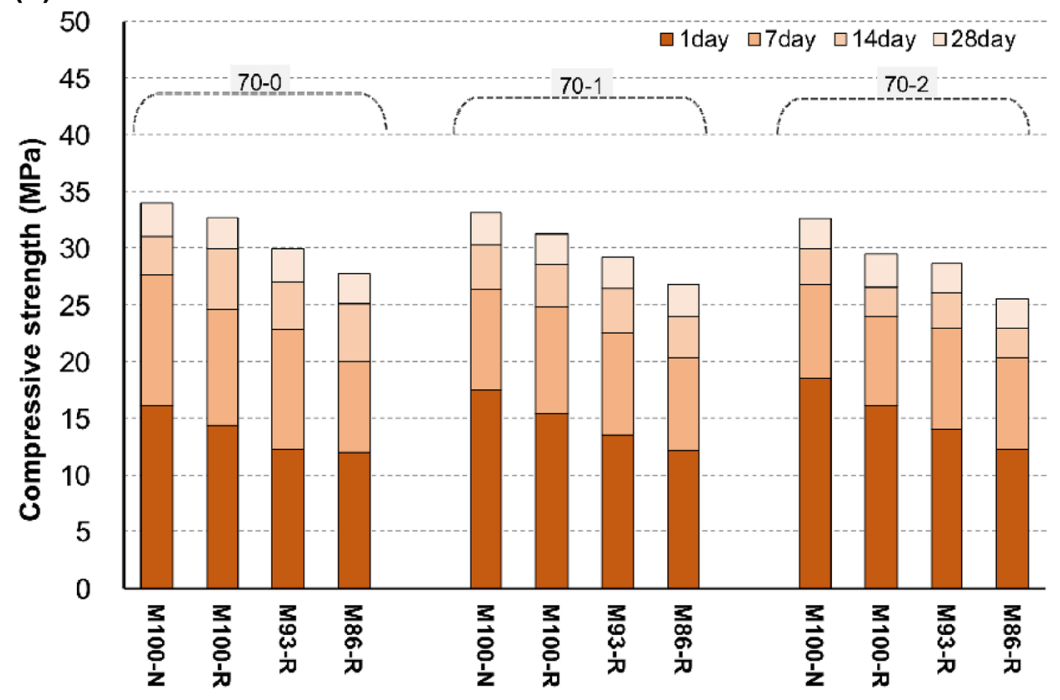


Fig. 7 Strength comparison of the steam-cured specimens with varying duration of holding the maximum temperature; $\mathbf{a} 0 \mathrm{~h}, \mathbf{b} 1 \mathrm{~h}$, and $\mathbf{c} 2 \mathrm{~h}$
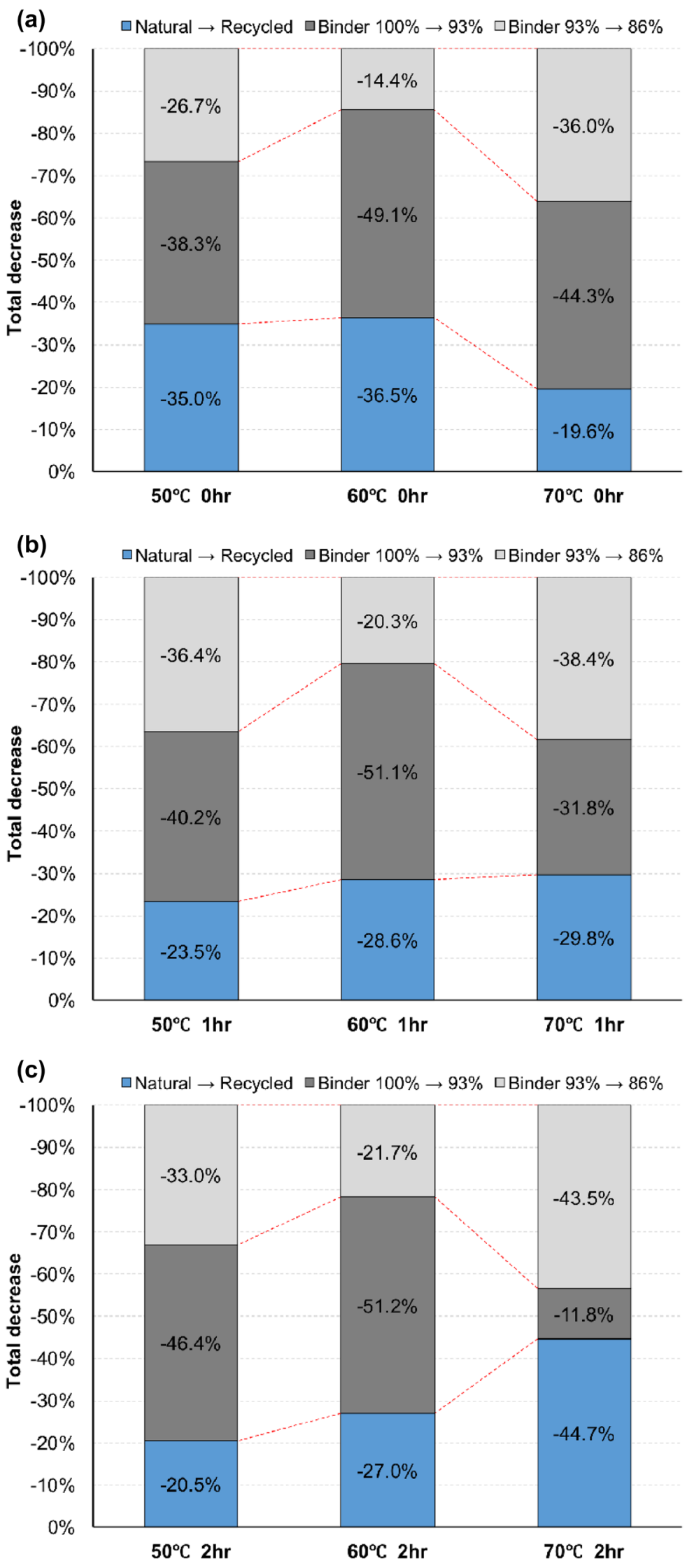
was optimum. Previously, Ramezanianpour et al. [32, 34] had shown that for self-consolidating concrete and for concrete containing mineral admixtures, a lower duration of exposure to the maximum temperature was more beneficial. The experimental findings in the current study corroborate similar outcomes for RAC. This clearly shows that maintaining the peak temperature for a greater time period is not of increased benefit. Not only is the strength reduced, but more resources (energy and cost) are also expended, which hinders the sustainability goals. It is also imperative to specify the higher rate of shrinkage due to the very high temperature.

Typically, the increased temperature is thought to increase the early strength of concrete due to an increased hydration reaction. However, this generalization cannot be guaranteed for a different cement type that has a moderately high early strength (as used in this study). Both the physical properties (fineness and surface area), and chemical composition, play a fundamental role in the rate of the hydration reaction. The fact that the tested concrete had a high compressive strength despite the recycled aggregate, low temperature steam curing, and short duration, may be due to the characteristics of the moderately high early strength cement.

It is also important to note that conventionallyproduced high early strength cement has a higher C3S content than ordinary Portland cement. Therefore, the early strength is high, and the hydration heat and drying shrinkage are increased, while the long-term strength is lower than that of ordinary Portland cement [2]. It is suggested that the lower content of C3S and the increased content of $\mathrm{C} 2 \mathrm{~S}$ in moderately high early strength cement lead to its improved attributes.

\section{Conclusions}

In this experimental study, the properties of steam-cured recycled aggregate concrete (RAC) incorporating moderately high early strength cement (MESC) were evaluated in an attempt to determine the optimum conditions of a steam-curing cycle for RAC as well as determining the potential of reducing binder volume in concrete by exploiting the benefits of steam curing. The objective was to (i) determine the feasibility of MESC in recycled aggregate concrete (RAC), (ii) determine the optimum steam curing conditions (curing duration, maximum temperature, and duration of holding maximum temperature), and (iii) evaluate the beneficial use of reduced binder content to compensate for steam curing. Four series of RAC were developed which were subjected to nine different steam curing condition, and the resulting strength properties were determined.

The following meaningful conclusions were drawn from this experimental study:

1. The optimum conditions for steam curing based on the strength criterion were a heating/cooling rate of $20^{\circ} \mathrm{C} / \mathrm{h}$ and a peak temperature of $50^{\circ} \mathrm{C}$, maintained for $1 \mathrm{~h}$.

2. In steam-cured RACs, and for other matters typical concretes, the binder volume content can be reduced by $7 \%$ without appreciable strength loss.

The research findings point towards low-cost and sustainable application for steam-cured RAC in precast concrete construction, where the objective is rapid construction with excellent mechanical properties. The use of recycled aggregates can slow the depletion of natural resources and help promote sustainable development. It is, however, clarified that the accelerated hydration for faster strength gain might lead to shrinkage and cracking, which must be evaluated prior to critical structural elements, particularly for structures with a higher ratio of surface area to depth, such as slabs and pavements. Nevertheless, the use of shrinkage-reducing admixtures or expansive cement can reduce the likelihood of such cracking. It is noteworthy, that MESC was sued in this experimental work instead of conventional high early strength cement (HESC) to mitigate potential shrinkage cracking. Although the use of steam-cured RAC with optimum duration and temperature conditions ought to maximize the resulting mechanical attributes, the cost of achieving this and the associated carbon dioxide emissions must also be evaluated to determine the overall impact.

Funding This work has supported by the National Research Foundation of Korea (NRF) grant funded by the Korea government (MSIT) (No. 2018R1C1B6009247) and supported by the National Research Foundation of Korea (NRF) Grant (No. NRF-2018R1D1A3B07045700) funded by the Korea government.

\section{Compliance with ethical standards}

Conflict of interest The authors declare no conflict of interest.

\section{References}

1. Taurino R, Barbieri L, Bondioli F (2016) Surface properties of new green building material after $\mathrm{TiO}_{2}-\mathrm{SiO}_{2}$ coatings deposition. Ceram Int 42:4866-4874. https://doi.org/10.1016/j.ceram int.2015.12.002 
2. Kim Y, Hanif A, Usman M, Munir MJ, Kazmi SMS, Kim S (2018) Slag waste incorporation in high early strength concrete as cement replacement: environmental impact and influence on hydration; durability attributes. J Clean Prod 172:3056-3065. https://doi. org/10.1016/j.jclepro.2017.11.105

3. Parthasarathy P, Hanif A, Shao H, Li Z (2017) Microstructural and morphological studies of ordinary portland cement paste and fly ash based geopolymer in the presence of chloride ions. In: 71st RILEM week and ICACMS 2017-international conference on advances in construction materials and systems, Chennai, India 3-8 September 2017, pp 623-631

4. Ding Z, Dong B, Xing F, Han N, Li Z (2012) Cementing mechanism of potassium phosphate based magnesium phosphate cement. Ceram Int 38:6281-6288. https://doi.org/10.1016/j. ceramint.2012.04.083

5. Lu Z, Hou D, Ma H, Fan T, Li Z (2016) Effects of graphene oxide on the properties and microstructures of the magnesium potassium phosphate cement paste. Constr Build Mater 119:107-112. https://doi.org/10.1016/j.conbuildmat.2016.05.060

6. Xu B, Ma H, Hu C, Yang S, Li Z (2016) Influence of curing regimes on mechanical properties of magnesium oxychloride cementbased composites. Constr Build Mater 102:613-619. https://doi. org/10.1016/j.conbuildmat.2015.10.205

7. Xu B, Ma H, Hu C (2015) Influence of cenospheres on properties of magnesium oxychloride cement-based composites. Mater Struct. https://doi.org/10.1617/s11527-015-0578-6

8. Hu C, Li Z, Gao Y, Han Y, Zhang Y (2014) Investigation on microstructures of cementitious composites incorporating slag. Adv Cem Res 26:222-232. https://doi.org/10.1680/adcr.13.00029

9. Hu C (2014) Microstructure and mechanical properties of fly ash blended cement pastes. Constr Build Mater 73:618-625. https:// doi.org/10.1016/j.conbuildmat.2014.10.009

10. Xiao J (2018) Recycled aggregate concrete. Springer Nature (Springer-Verlag GmbH Germany), Berlin. https://doi. org/10.1007/978-3-662-53987-3

11. Torgal FP, Ding Y (eds) (2013) Handbook of recycled concrete and demolition waste, 1st edn. Woodhead Publishing Limited, Sawston

12. Zegardło B, Szeląg M, Ogrodnik P (2018) Concrete resistant to spalling made with recycled aggregate from sanitary ceramic wastes - the effect of moisture and porosity on destructive processes occurring in fire conditions. Constr Build Mater 173:5868. https://doi.org/10.1016/j.conbuildmat.2018.04.030

13. Cachim PB (2009) Mechanical properties of brick aggregate concrete. Constr Build Mater 23:1292-1297. https://doi. org/10.1016/j.conbuildmat.2008.07.023

14. Adaway M, Wang Y (2015) Recycled glass as a partial replacement for fine aggregate in structural concrete-effects on compressive strength. Electron J Struct Eng 14:116-122

15. Ismail ZZ, AL-Hashmi EA (2008) Use of waste plastic in concrete mixture as aggregate replacement. Waste Manag 28:2041-2047. https://doi.org/10.1016/j.wasman.2007.08.023

16. Hanif A, Kim Y, Lee K, Park C, Sim J (2017) Influence of cement and aggregate type on steam-cured concrete-an experimental study. Mag Concr Res 69:694-702. https://doi.org/10.1680/jmacr .17 .00015

17. Hanif A, Kim Y, Lu Z, Park C (2017) Early-age behavior of recycled aggregate concrete under steam curing regime. J Clean Prod 152:103-114. https://doi.org/10.1016/j.jclepro.2017.03.107

18. Kheder GF (2005) Variation in mechanical properties of natural and recycled aggregate concrete as related to the strength of their binding mortar. Mater Struct 38:701-709. https://doi. org/10.1617/14216

19. Xiao JZ, Li JB, Zhang C (2006) On relationships between the mechanical properties of recycled aggregate concrete: an overview. Mater Struct 39:655-664. https://doi.org/10.1617/ s11527-006-9093-0

20. Ismail S, Ramli M (2014) Mechanical strength and drying shrinkage properties of concrete containing treated coarse recycled concrete aggregates. Constr Build Mater 68:726-739. https:// doi.org/10.1016/j.conbuildmat.2014.06.058

21. Kou SC, Poon CS, Agrela F (2011) Comparisons of natural and recycled aggregate concretes prepared with the addition of different mineral admixtures. Cem Concr Compos 33:788-795. https://doi.org/10.1016/j.cemconcomp.2011.05.009

22. Spaeth V, Tegguer AD (2013) Improvement of recycled concrete aggregate properties by polymer treatments. Int J Sustain Built Environ 2:143-152. https://doi.org/10.1016/j.ijsbe.2014.03.003

23. Lu L, Zhao P, Lu Z (2018) A short discussion on how to effectively use graphene oxide to reinforce cementitious composites. Constr Build Mater 189:33-41. https://doi.org/10.1016/j.conbuildma t.2018.08.170

24. Lu Z, Hou D, Meng L, Sun G, Lu C, Li Z, Lu C, Li Z (2015) Mechanism of cement paste reinforced by graphene oxide/carbon nanotubes composites with enhanced mechanical properties. RSC Adv 5:100598-100605. https://doi.org/10.1039/c5ra1 $8602 \mathrm{a}$

25. Saleem Kazmi SM, Munir MJ, Wu Y-F, Patnaikuni I, Zhou Y, Xing $F$ (2019) Axial stress-strain behavior of macro-synthetic fiber reinforced recycled aggregate concrete. Cem Concr Compos. https://doi.org/10.1016/j.cemconcomp.2019.01.005

26. Kazmi SMS, Munir MJ, Wu YF, Patnaikuni I (2018) Effect of macrosynthetic fibers on the fracture energy and mechanical behavior of recycled aggregate concrete. Constr Build Mater 189:857868. https://doi.org/10.1016/j.conbuildmat.2018.08.161

27. Ahmad J, Usman M, Hassan MA, Farooq SH, Hanif A (2018) Enhancing lateral load performance of traditional timber wall (Dhajji-Dewari) by strengthening of joints. IOP Conf Ser Mater Sci Eng 431:072002. https://doi.org/10.1088/1757899X/431/7/072002

28. Hanif A, Kim Y, Kang T, Lee T, Jo C, Sim J (2011) A study on the compressive strength of precast concrete using recycled aggregate concrete. In: Korea Concrete Institute Spring Convention 2011, Jeju, Korea

29. Hanif A, Kim Y, Lee H, Park C, Sim J (2011) Suitability assessment of reinforced precast concrete blocks incorporating recycled aggregate. In: Korea Concrete Institute Autumn Convention 2011

30. Schmidt M, Amrhein K, Braun T, Glotzbach C, Kamaruddin S, Tänzer R (2013) Nanotechnological improvement of structural materials-Impact on material performance and structural design. Cem Concr Compos 36:3-7. https://doi.org/10.1016/j. cemconcomp.2012.11.003

31. Hanif A, Kim Y, Usman M, Park C (2018) Optimization of steamcuring regime for recycled aggregate concrete incorporating high early strength cement-a parametric study. Materials 11:2487. https://doi.org/10.3390/ma11122487

32. Ramezanianpour AA, Khazali MH, Vosoughi P (2013) Effect of steam curing cycles on strength and durability of SCC: a case study in precast concrete. Constr Build Mater 49:807-813. https ://doi.org/10.1016/j.conbuildmat.2013.08.040

33. Ba MF, Qian CX, Guo XJ, Han XY (2011) Effects of steam curing on strength and porous structure of concrete with low water/binder ratio. Constr Build Mater 25:123-128. https://doi. org/10.1016/j.conbuildmat.2010.06.049

34. Ramezanianpour AM, Esmaeili K, Ghahari SA, Ramezanianpour AA (2014) Influence of initial steam curing and different types of mineral additives on mechanical and durability properties of self-compacting concrete. Constr Build Mater 73:187-194. https ://doi.org/10.1016/j.conbuildmat.2014.09.072 
35. Kosmatka SH, Kerkhoff B, Panarase WC (2008) Design and control of concrete mixtures, 14th edn. Portland Cement Association (PCA), USA

36. Park JS, Kim YJ, Cho JR, Jeon SJ (2015) Early-age strength of ultrahigh performance concrete in various curing conditions. Materials 8:5537-5553. https://doi.org/10.3390/ma8085261

37. Türkel S, Alabas V (2005) The effect of excessive steam curing on Portland composite cement concrete. Cem Concr Res 35:405411. https://doi.org/10.1016/j.cemconres.2004.07.038

38. Kou SC, Poon CS, Chan D (2004) Properties of steam cured recycled aggregate concrete. In: International RILEM conference on the use of recycled materials in buildings and structures 8-11 November 2004, Barcelona, Spain, pp 590-599. https://www.scopus.com/ record/display.uri?eid=2-s2.0-33644940010\&origin=resultslis $\mathrm{t} \&$ sort $=$ plf-t\&src=s\&st $1=$ shrinkage $+\& \mathrm{st} 2=$ steam \&searchTerm $\mathrm{s}=$ recycled+concrete $\% 3 \mathrm{~F} \% 21 \% 22 * \% 24 \&$ sid $=49 \mathrm{bc} 90 \mathrm{f} 9925 \mathrm{de} 10$ $826 \mathrm{e} 2 \mathrm{~b} 52 \mathrm{c} 8 \mathrm{ac} 53 \mathrm{e} 53 \& \mathrm{sot}=\mathrm{b} \& \mathrm{sdt}=\mathrm{b} \& \mathrm{~s}=88 \& \mathrm{~s}=\% 28 \mathrm{TITLE}-\mathrm{ABS}-$ KEY\%28shrinkage+

39. Fonseca N, De Brito J, Evangelista L (2011) The influence of curing conditions on the mechanical performance of concrete made with recycled concrete waste. Cem Concr Compos 33:637-643. https://doi.org/10.1016/j.cemconcomp .2011 .04 .002

40. Korean Standards, KS F 2573-2006 (2006) Recycled aggregate for concrete. Korean Standards, Republic of Korea

41. Korean Standards, KS F 2502-2010 (2010) Standard test method for sieve analysis of fine and coarse aggregate. Korean Standards, Republic of Korea

42. Korean Standards, KS F 2504-2007 (2007) Testing method for density and absorption of fine aggregate. Korean Standards, Republic of Korea

43. Korean Standards, KS F 2503-2007 (2007) Testing method for density and absorption of coarse aggregate. Korean Standards, Republic of Korea

44. ACl Committee 211 (2002) Standard Practice for Selecting Proportions for Normal, Heavyweight, and Mass Concrete (ACI 211.1-91)

45. ACl Committee 318 (2008) Building Code Requirements for Structural Concrete ( $\mathrm{ACl} 318 \mathrm{M}-08)$

46. Lee $H$, Hanif A, Usman M, Sim J, Oh H (2018) Performance evaluation of concrete incorporating glass powder and glass sludge wastes as supplementary cementing material. J Clean Prod. https://doi.org/10.1016/j.jclepro.2017.09.133

47. Kim Y, Hanif A, Kazmi SMS, Munir MJ, Park C (2018) Properties enhancement of recycled aggregate concrete through pretreatment of coarse aggregates-comparative assessment of assorted techniques. J Clean Prod 191:339-349. https://doi. org/10.1016/j.jclepro.2018.04.192

48. Hanif A (2017) Recycled aggregate use in precast concrete: properties \& applications (ISBN: 978-3-330-07808-6). LAMBERT Academic Publishing, Germany

49. Sim J, Park C, Park S, Kim Y (2006) Characterization of compressive strength and elastic modulus of recycled aggregate concrete with respect to replacement ratios. J Korean Soc Civ Eng $26: 213-218$
50. ASTM C39 (2003) C 39/C 39M-99 standard test method for compressive strength of cylindrical concrete specimens. American Society for Testing and Materials

51. ASTM C143-03 (2003) Standard test method for slump of hydraulic-cement concrete. American Society for Testing and Materials

52. ASTM C231-04 (2004) Standard test method for air content of freshly mixed concrete by the pressure method. American Society for Testing and Materials. https://doi.org/10.1520/c0231

53. Li Z (2011) Advanced concrete technology. Wiley, New York

54. ASTM C469-94 (1994) C 469-94 standard test method for static modulus of elasticity and Poisson's ratio of concrete. American Society for Testing and Materials. https://doi.org/10.1520/c0469

55. Usman M, Khan AY, Farooq SH, Hanif A, Tang S, Khushnood RA, Rizwan SA (2018) Eco-friendly self-compacting cement pastes incorporating wood waste as cement replacement: a feasibility study. J Clean Prod 190:679-688. https://doi.org/10.1016/j.jclep ro.2018.04.186

56. Neville AM (2004) Properties of concrete, 4th edn. Pearson Education, London

57. de Brito J, Saikia N (2006) Recycled aggregate in concrete: use of industrial, construction and demolition waste. Bentham Science Publishers, Sharjah. https://doi.org/10.2174/978160805285110 60101

58. Kim Y, Hanif A, Usman M, Park W (2019) Influence of bonded mortar of recycled concrete aggregates on interfacial characteristics - porosity assessment based on pore segmentation from backscattered electron image analysis. Constr Build Mater 212:149-163. https://doi.org/10.1016/j.conbuildma t.2019.03.265

59. Lin TD (1998) Effects of water-cement ratio, curing age, silica fume, polymer admixtures, steel surface treatments and corrosion on the bond between concrete and steel reinforcing bar. ACI Mater J 95:725-734. https://doi.org/10.14359/417

60. Lin W-M, Lin TD, Hwang CL, Peng YN (1998) A fundamental study on hydration of cement with steam. ACI Mater J 95:37-49. https ://doi.org/10.14359/350

61. Wade S (2005) Evaluation of the maturity method to estimate concrete strength. Mater of Science Thesis Auburn University, Alabama, Auburn University. http://hdl.handle.net/10415/127

62. Wedding P, Carino N (1984) The maturity method: theory and application. Cem Concr Aggreg 6:61. https://doi.org/10.1520/ CCA10358J

63. Poon CS, Chan D (2006) Paving blocks made with recycled concrete aggregate and crushed clay brick. Constr Build Mater 20:569-577. https://doi.org/10.1016/j.conbuildmat.2005.01.044

Publisher's Note Springer Nature remains neutral with regard to jurisdictional claims in published maps and institutional affiliations. 